\title{
Vulnerability of the Tibetan Pastoral Systems to Climate and Global Change
}

\author{
Yang Wang ${ }^{1}$, Jun Wang ${ }^{2}$, Shuangcheng Li $^{1}$ and Dahe Qin ${ }^{1,3}$
}

\begin{abstract}
The impacts of climate and global change on Tibetan pastoral systems have become increasingly evident. Thus, a significant research endeavor is to explore the combined effects of these changes on the livelihoods of herder households and communities, on the adaptation strategies they adopted to respond to the current and expected risks associated with these changes, and on the emerging opportunities that can strengthen their resilience and adaptive capacity. We performed an integrated analysis of the dynamics of Tibetan pastoral systems influenced by climate and global changes by using the analytical framework developed by Ostrom. Climate and global changes have significantly altered the attributes of and the interactions within Tibetan pastoral systems, thus posing great challenges to their sustainable development. We used Nagqu County, a remote area of the northern Tibetan Plateau of China, as a case study to analyze the adaptation strategies adopted by local herders to respond to multiple stressors, as well as the emerging opportunities that they can take advantage of to increase their adaptive capacity. Findings show that although local herders have developed various adaptation strategies, such as planting forage grass, buying fodder from the market, renting pastures, joining formal or informal cooperatives, and diversifying livelihoods, social, cultural, and institutional challenges still exist. To enhance the adaptive capacity of herders and to reduce their vulnerability, we recommend that future rangeland policies and programs promote: (1) comprehensive support for formal or informal pastoral cooperatives, (2) development of the rangeland economy to take advantage of the multifunctionalities of rangeland ecosystems, and (3) revitalization of the mobility paradigm to allow the flexible use of rangelands.
\end{abstract}

Key Words: adaptation; climate change; global change; herders; livelihood; Tibetan Plateau; vulnerability

\section{INTRODUCTION}

Herder communities on the Tibetan Plateau, which typically rely on ecosystem services provided by local grassland ecosystems, are becoming increasingly vulnerable to climate change and socialinstitutional changes. Climate change has been evident on the Tibetan Plateau over the past decades (Wu et al. 2007). According to International Panel on Climate Change (IPCC) AR4, the mean surface temperature on the Tibetan Plateau has increased by $0.3^{\circ}$ $\mathrm{C}$ per decade over the past 50 years; this value is approximately 3 times the global warming rate. Future warming on the plateau is also predicted to be well above the global mean (Christensen et al. 2007). Temporal precipitation trends have also varied across the Tibetan Plateau over the past decades (Wu et al. 2005). Overall, precipitation has increased by approximately $3.4 \mathrm{~mm}$ per decade over the past 50 years. Winter precipitation has been increasing, whereas summer precipitation has decreased slightly. Future precipitation is expected to increase in the southeast and central plateau regions (Wilkes 2008). The locations of climate zones on the Tibetan Plateau will change because of warmer temperature (Zhao et al. 2002). Permafrost on the Tibetan Plateau has been predicted to largely disappear, which will accelerate grassland desertification (Ni 2003). Recent studies have shown that warming has decreased vegetative productivity and plant species diversity as well as shortened the growing seasons of vegetation (Klein et al. 2004, 2007, Yu et al. 2010).

Aside from experiencing evident climate change, herder communities on the Tibetan Plateau have also witnessed dramatic social-institutional transformations over the past decades. Herder communities are increasingly linked to the rapid economic development in China; such development offers both opportunities and challenges for herder communities (Kreutzmann 2011). On one hand, integration into the rapid growing Chinese economy could provide more opportunities for herders to increase their household income by expanding livestock production and diversifying their livelihood choices (Nyima 2003). On the other hand, transformations in socialcultural institutions may undermine the adaptation capacity of herder communities to climate variability and change. Recent studies found that privatization and grazing sedentarization have reduced the flexibility of grassland resource use by herders $(\mathrm{Wu}$ and Yan 2002, Bauer 2005, Richard 2005, Yan et al. 2005, Foggin 2008, Klein et al. 2011, Du 2012, Tashi and Foggin 2012). Along with climate change, social-institutional change has affected the livelihood of herders on the Tibetan Plateau. Although numerous researchers have noted the climatic and social-institutional changes on the Tibetan Plateau over the past decades, a systematic investigation of the effects on local herder communities remains lacking (Dong et al. 2011). We fill this research gap by (1) performing an integrated analysis of the grassland socialecological systems (SES) on the Tibetan Plateau by using the analytical framework developed by Ostrom (2009), and (2) analyzing the adaptation strategies adopted by local herders to respond to multiple stressors and the emerging opportunities, which can enable herders to increase their adaptive capacity.

\section{DYNAMICS OF THE TIBETAN RANGELAND SOCIAL- ECOLOGICAL SYSTEMS}

Social, economic, and political contexts

Tibetan pastoral systems were historically based on subsistence and self-reliant family or clan economies. Mobility and flexible 
use of resources have enabled herders on the Tibetan Plateau to adapt to the harsh environment. However, the government perceived nomadic pastoralism as a backward or inefficient method of land and livestock management that had to be abolished (Goldstein and Beall 1990). Based on this assumption, the government sponsored a number of development programs to sedentarize the grasslands (Yeh 2005). Sedentarization was believed to make access to social services convenient for the nomads, and the program was expected to aid in the integration of nomads into the Chinese mainstream or modern society. However, the modernization process did not resolve the development problems of pastoral communities, but rather weakened the basis of traditional pastoral livelihoods.

\section{Resource systems}

As one of the most important grazing ecosystems in the world, rangelands of the Tibetan Plateau supply forage for an estimated 12 million yaks and 30 million sheep and goats, as well as support the livelihoods of approximately 2 million pastoralists and 3 million agro-pastoralists (Miller 2005). Approximately a third of the Tibetan Steppe is considered moderately to severely degraded (Miller 2005). Although the dynamics of this degradation are not well understood, the impacts of climate change and policy interventions are widely acknowledged (Dong et al. 2011). Results from observation and experimental studies demonstrated that warming generally had negative impacts on some key vegetative properties on the plateau. For example, warming in the absence of grazing caused a significant decrease in overall vegetative production and plant diversity (Klein et al. 2004, 2008). Warming also delayed the reproductive phenology of the dominant species (Kobresia pygmaea) in the alpine meadow ecosystem (Dorji et al. 2013). Current rangeland management policies serve an important function in rangeland degradation. The change in livestock distribution caused by changes in property rights is more likely to intensify pressures on some pastures, thus resulting in distributed overgrazing because of uneven resource systems (Yan et al. 2005).

\section{Resource units}

Herders on the plateau usually tend to a mix of livestock in terms of species and class, e.g., yak, sheep, goats, and horse, to maximize the use of rangeland resources while minimizing the risk of livestock loss from extreme weather events (Miller 2005). The yak is native to high altitude areas, and Tibetan nomads place a significant value on these them. As a matter of fact, the Tibetan term for yaks, 'nor,' also translates to wealth. Although the yak is considered a typical Tibetan animal, sheep and goats are more economically important because these animals can produce highvalue products, such as milk, meat, wool, and skins. Horses generally comprise a small portion of Tibetan nomads' herds and are typically used for transportation.

Severe snowstorms, especially in the early winter or spring, bury forage and prevent livestock from grazing. Thus, snowstorms are the most significant environmental risk that affects the livelihoods of local herders. Statistics show that more than 18 million livestock died because of snowstorms from 1974 to 2009 in the eastern part of the plateau (Long et al. 2011). The snowstorms of 1997 to 1998, in which millions of livestock perished, were particularly devastating and were, in many places, the worst in living memory (Wu and Yan 2002). Moreover, climate models predict that the frequency and intensity of snowstorms on the plateau may increase, thus adding more challenges to the vulnerable SES (Christensen et al. 2007).

Driven by the increasing demand for livestock products, particularly meat and milk, the number and structure of Tibetan livestock systems are in transition. During the past decades, the total number of livestock in Tibet has significantly increased, particularly during 1965 to 1980 , with a growth rate of higher than $35 \%$ (Long et al. 2011). A field study conducted in the Aru basin of Tibet's Chang Tang showed that goats are becoming important because of the value of cashmere wool in national and international markets. The male/female ratio of goats has also significantly changed because the adult male goats tend to yield more and better quality cashmere than females (N æss et al. 2004).

The interactions between livestock, i.e., resource units, and rangeland resources, i.e., resource systems, are complex. Overgrazing is widely acknowledged to be a significant contributor to grassland degradation on the plateau, which consequently decreases the productive performance of livestock. However, light and moderate grazing might have positive effects on rangeland biomass and plant diversity (Wilkes 2008).

\section{Governance systems}

For thousands of years, herders on the plateau have developed a sophisticated arrangement of rangelands and livestock and have practiced various adaptation strategies to mitigate risks and avert disasters by using their comprehensive local ecological knowledge about local climatic patterns, rangeland ecology, and livestock management (Goldstein and Beall 1990, Miller 2005, Klein et al. 2011, Fu et al. 2012). The most important adaptation strategies are multispecies grazing, mobility, reserving pasture, and networks of reciprocity (Klein et al. 2011).

Since the 1950s, government systems have undergone fundamental changes. The major reforms, which affected pastoralism on the Tibetan Plateau, include collectivization in the 1960 s and 1970s, reform and opening up in the 1980s, and privatization since the late 1990s. In the stage of collectivization, all livestock was the property of the communes. Herders were transformed to holders of a share in the communes' livestock (Miller 2005). The basic accounting unit was the production team. Labor forces in the production team had to work for the commune to obtain work points, cash, or provisions for their families (Goldstein and Beall 1990). In the early 1980s, the Household Responsibility Program (HRP) was introduced from the agricultural area of China to the Tibetan pastoral area. The program aimed to prevent the practice of 'Ren Chi Da Guo Fan, 'i.e., everyone eats from the same big pot, no matter how much they have contributed, which was believed to be the root cause of low production efficiency because of the lack of incentive ( $\mathrm{Li}$ and Huntsinger 2011). The decollectivization process then started. In this process, communal livestock was distributed among households according to size (Banks et al. 2003). However, at this stage, pastures were still assigned to groups organized in a manner similar to communities. The fact that the nomads privately owned the livestock and that the pastures were commonly shared among the group members raised the government's concern that nomads would want to maximize their short-term interest at the cost of 
the environment (Wu and Richard 1999). To avoid the so-called tragedy of the commons, rangelands were further allocated to individual households by contract (Yan et al. 2005).

A common belief was that clearly defining individual property rights would make herders more responsible in limiting their herd size and investing in rangeland improvements for sustainable rangeland management. However, minimal evidence is available on the improvement of rangeland conditions. Instead, with decreased seasonal mobility and flexibility within livestock management practices, more intractable problems have emerged, such as increased labor inputs, boundary conflicts, security concerns, wildlife mobility problems, and greater difficulty in accessing water resources (Yan et al. 2005). The central government then implemented new programs and policies, such as converting pastures to rangelands and ecological migration (Foggin 2008). These policies would undoubtedly further upset the balance within the social-ecological systems in which herders, livestock, and rangelands have coevolved for millions of years.

\section{Users/actors}

The number of direct and indirect users of rangeland resources has recently increased significantly. This condition could be attributed to rapid population growth and the improvement in people's living standards. The total population of Tibet increased from 1.23 million in 1959 to 2.87 million in 2008 (Long et al. 2011). With the opening of the Qinghai-Tibet railway, more immigrants are expected to reside in the traditional pastoral region. The number of livestock would also increase correspondingly, thus resulting in rangeland degradation and a threatening of the sustainability of future pastoral livelihoods (Dong et al. 2011).

The impacts of climate and socioeconomic changes on resource users are in evidence, and local herders perceive and feel the effects of climate change. Herders believe that climate change adversely affects rangeland health, hence, they tend to employ new adaptation strategies, such as planting forage grass, buying fodder from the market, and renting pastures, to cope with fodder shortage caused by climate change and livestock growth (Yan et al. 2011). With the socioeconomic changes, the sources of income for Tibetan pastoralists are highly diversified, draw on animal husbandry as their basis, and are augmented by government salaries, proceeds from wage labor, and incomes from trade and entrepreneurship (Kreutzmann 2011).

\section{Action situations}

Action situations and actors are two features that make up the action arena, which is the focal point of the Institutional Analysis and Development Framework (IAD; Ostrom 2005). When integrating the IAD into a broader framework for SES, the IAD is simplified to focus on the action situation that leads to interactions and outcomes (Ostrom 2011).

Action situations are partially dependent on rules (Ostrom 2011). Socioeconomic changes on the plateau have altered the working rules, specifically the boundary rules, which affect the structure of local herders' action situation. Traditional pastoralists practiced flexible management by maintaining flexible physical boundaries for grassland use, as well as flexibility in the membership of the groups that use the rangeland. However, the HRP established a hardened, inflexible boundary both for the resources and the user groups. This boundary weakened the ability of herders to use a flexible spatial scale or mobility to benefit from grassland resources (Yan et al. 2005, Richard et al. 2006, Li and Huntsinger 2011).

\section{STUDY AREA AND METHOD}

The case study was conducted in Nagqu County, a remote area on the northern Tibetan Plateau (Fig. 1). Nagqu County covers approximately $16,200 \mathrm{~km}^{2}$ and has a population of 91,859 (2011). With an elevation of approximately $4500 \mathrm{~m}$, Nagqu has a harsh alpine climate with long, cold, dry winters and short, cool summers. Snowstorms frequently occur in this region. The available rangeland area in this county is approximately 10,500 $\mathrm{km}^{2}$, which supply forage for an estimated 900,000 head of livestock, including 400,000 head of large livestock, mainly yak, and 500,000 head of sheep and goats. In August 2009, Nagqu was chosen to host the largest logistics center on the Qinghai-Tibet railway. The Nagqu Railway Station is the confluence of national roads G317 and G109 and provincial highway S305.

Fig. 1. Location of the study area.

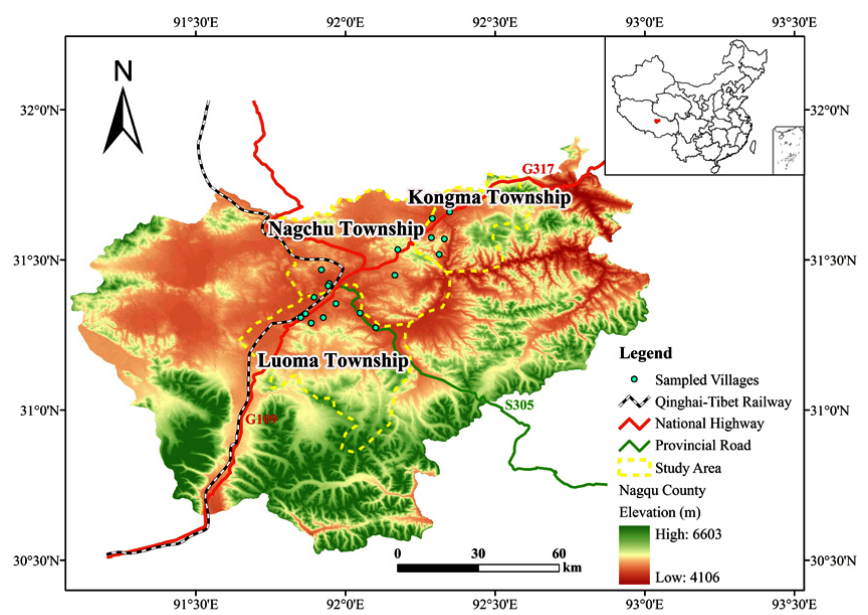

Field surveys were conducted by using semistructured interviews at places with different socioeconomic attributes, such as distance to the road and distance to the town center, from July to September 2011. Stratified random sampling was used to select households in each study site based on their wealth ranking. A total of 136 households, including 41 from 5 natural villages in Nagqu Town, 45 from 8 natural villages in Luoma Town, and 50 from 4 natural villages in Kongma Town, were surveyed. Six trained enumerators (in pairs, divided into three groups) collected the data by using face-to-face semiopen questionnaires. Each questionnaire was completed within 1.5 to 2 hours. The survey consisted of six sections: (1) basic socioeconomic information, e.g., demographic information, family income, and expenditures; (2) livestock inventory; (3) pasture use and management; (4) impacts of climate change; (5) effects of socioeconomic change; (6) livelihood adaptation strategies; and (7) future plans. The survey data provided essential information to assess the effects of climate and global change on local herders' livelihoods. Data were analyzed by using SPSS 18 and Microsoft Excel 2007. 


\section{VULNERABILITY ANALYSIS}

\section{Vulnerability to climate variation and change}

According to statistical data from the Nagqu Meteorological Station, local annual mean temperature and annual precipitation increased over the past 50 years (Shang et al. 2010). A warmer climate is favorable for winter rangeland pests, which are poisonous if ingested by livestock. The survey showed that herders in Luoma Town were the most exposed to rangeland pests; 24 households were affected and 7 head of yak died in 2011. The increase in summer rainstorms has also posed a great threat to the livelihood of herders in the study area. Heavy rains and floods could easily destroy substandard houses made of mud and yak dung. A village cadre in Nagqu Town reported that three households in his village lost their permanent houses because of a flood in 2011; the members of the households currently live in temporary tents.

In the winters of 1997 to 1998 , tens of thousands of herders in Nagqu County suffered heavy livestock losses because of severe snowstorms. Approximately a quarter of the surveyed households, i.e., 32 households, lost a great part of their livestock at that time. Some, i.e., 11 households, became completely bankrupt and had to rely on government relief. However, some herders were fortunate. In Renmao Village (Nagqu Town), a formal pastoral cooperative was established after the snowstorms with the aid of the local government. The cooperative provided herders with a piece of reserved pasture and a certain amount of low-interest loans. The manager of the cooperative shared that the 2010 annual revenue of the cooperative reached 400,000 yuan renminbi $(\mathrm{RMB}$; 1 dollar $=6.8 \mathrm{RMB})$. Aside from paying the employees' wages and buying livestock for reproduction, the revenue was used to help other poor households in Nagqu Town.

\section{Vulnerability to globalization}

\section{Privatization of rangeland use rights}

The process of rangeland privatization was implemented in the study area started in the 1990s and was divided into two phases. Phase I involved allocating rangeland to each natural village, and phase II involved allocating rangeland to each household within that village. The survey indicated that 78 households completed the two phases and now have their own winter and summer pastures. Twenty-one households are in phase II, because their winter pastures can be individually used, but the summer pastures are commonly used. The others' pastures are still commonly used by their village members. However, the process of rangeland privatization will be accelerated, according to a government officer, who stated the program will cover at least $90 \%$ of the herders in Nagqu by the end of 2011.

Scholars of rangeland management (Miller 2005, Yan et al. 2005) have argued that although the policy could improve the delivery of social services, in many instances, such a policy still conflicts with the goal of maintaining the sustainability of the rangeland SES because it limits the mobile nature of pastoralism. Local herders also expressed their concerns about the policy. For example, 28 households shared that "after rangeland privatization, the pastures that households receive are too small for herd movement," and 17 households stated "labor shortage is becoming a big problem. Some of the workload had to be transferred to women and children."
Most of the pastures were allocated to individual households. Thus, herders in the study area would have to pay a higher price to use others' pastures. The practice of reciprocal use of pastures continues to disappear and is being replaced by formal contracts. In the survey, 18 households mentioned that they previously signed pasture rental contracts. Ten households rented pastures for months, mainly during the winter months, to years and paid the pasture owners in cash, livestock, or milk products. Two households rented pastures and agreed to herd the pasture owners' livestock, trading their labor for access to additional land. One household contracted out part of their livestock herd to their relatives. Thirteen pasture-lease contracts were signed among individual households. The survey also revealed contracts that involved five households had been signed among the villages. A village head in Kongma Town shared that herders in their village have maintained cooperative relations with those in $B$ village since 2002. Their village herders can use the pastures of B village. Meanwhile, herders of B village can dig caterpillar fungus on their pastures.

\section{Sedentarization and fencing}

Sedentarization efforts have been a part of Chinese policies on the Tibetan Plateau since the 1960s, with the primary goal of improving the rangeland ecosystem and the socioeconomic status of nomadic households. The program was supported by the government through different projects, such as the Project to Increase Living Comfort, 'wenbao gongcheng,' introduced in 1978; the Four Completions Project, 'sipeitao,' of the 1990s; and the Nomadic Settlement Project of the 2000s. The survey revealed that almost all households (117 households) have been involved in the Nomadic Settlement Project. According to the household size and number of livestock, each household could obtain a 10,000 to $20,000 \mathrm{RMB}$ housing subsidy. However, the project changed the lifestyle of the Tibetan nomads. The hasty implementation of the project, which caused local herders to change their lifestyles from a nomadic way of life to a settled way of life, has made it difficult for them to adapt (Ptackova 2011).

In pastoral areas, fencing is considered one of the most effective development interventions. Fencing is based on an economic logic, which assumes that if people owned their land, they would invest more resources in managing, improving, or conserving it (Bauer 2005). In the study area, fencing is simultaneously implemented with the process of rangeland privatization. In phase I of rangeland privatization, fences can be collectively constructed by households in the natural village. In phase II, fences will be individually constructed by each household. Although the government would shoulder part of the fencing cost for particular cases, the cost would still be very expensive for the herders. Pastoralists, 24 households, who answered the survey, expressed that they cannot afford to buy fences. However, 10 households believed that without fences, prohibiting others' livestock from grazing in their pastures would be difficult. Hence, boundary conflicts have been increasing. Nine households shared that they still decided to construct the fences collectively and commonly use their pastures. As an elder herder mentioned: "Now, some of my neighbors regret building their own fences because pasture quality is uneven. Some key resources, such as good quality pastures and wells, are no longer accessible to them." 
Table 1. Number of surveyed households whose pastures have degraded.

\begin{tabular}{|c|c|c|c|c|c|c|c|}
\hline \multirow[t]{2}{*}{ Town } & \multicolumn{3}{|c|}{$\begin{array}{c}\text { Summer pasture degradation } \\
\text { (\# of households) }\end{array}$} & \multicolumn{3}{|c|}{$\begin{array}{l}\text { Winter pasture degradation } \\
\text { (\# of households) }\end{array}$} & \multirow[t]{2}{*}{ Selected oral accounts from interviewees } \\
\hline & Light & Medium & Severe & Light & Medium & Severe & \\
\hline Nagqu & $23 / 41$ & $9 / 41$ & $7 / 41$ & $14 / 41$ & $9 / 41$ & $3 / 41$ & $\begin{array}{l}\text { "In the past, the forage height can reach } \\
\text { more than } 10 \mathrm{~cm} \text {, but now it is usually less } \\
\text { than } 7 \mathrm{~cm} \text {. In some areas, it is even less } \\
\text { than } 5 \mathrm{~cm} . \text {." (grass height) }\end{array}$ \\
\hline Luoma & $21 / 45$ & $11 / 45$ & $6 / 45$ & $20 / 45$ & $8 / 45$ & $5 / 45$ & $\begin{array}{l}\text { "In the past, the grass layer was dense and } \\
\text { tight, but now you can see the bare soil } \\
\text { below it." (the degree of grass cover) }\end{array}$ \\
\hline Kongma & $30 / 50$ & $12 / 50$ & $4 / 50$ & $27 / 50$ & $10 / 50$ & $3 / 50$ & $\begin{array}{l}\text { "In the past, there are few poisonous } \\
\text { weeds and forbs in this area, but now they } \\
\text { are common." (the proportion of noxious } \\
\text { weeds) }\end{array}$ \\
\hline Total & $74 / 136$ & $32 / 136$ & $17 / 136$ & $61 / 136$ & $27 / 136$ & $11 / 136$ & $\begin{array}{l}\text { "There are more and more pika in recent } \\
\text { years. Now you can see the pika hole } \\
\text { everywhere." (number of pika) }\end{array}$ \\
\hline
\end{tabular}

Driven by the combined effects of climate and social-institutional change, i.e., privatization of rangeland use rights, sedentarization, and fencing, the degree of degradation of local pastures varied (Table 1). Local pasture degradation was determined based on five indicators, i.e., grass height, degree of grass cover, proportion of noxious weeds, extent of grassland desertification, and number of pika. Three grades of grassland degradation were identified: light degradation, medium degradation, and severe degradation. Light degradation is characterized by decreased grass height and coverage. Medium degradation is characterized by an increased proportion of weeds and noxious grasses. The main feature of severe degradation is grassland desertification. As shown in Table 1 , grasslands in the study area were predominantly lightly degraded. Approximately $54 \%$ of the surveyed households mentioned that the grass height or grass coverage of their summer pastures decreased, and $45 \%$ stated the decrease in winter pastures. Most of the severely degraded pastures were near national roads and villages. The degradation of the summer pastures was more serious than that of the winter pastures, probably because grazing pressures are more condensed on the open areas, i.e., only $57 \%$ of summer pastures are contracted by individual households.

Rangeland degradation negatively affects livestock production and local herders' livelihoods. Table 2 shows the average productive performances of yak in the study area. Compared with the data collected by Yang (2002), meat and milk yields have decreased by $6.97 \%(2.92 \%)$ and $30.84 \%$ (15.80\%), respectively, over the last 20 (10) years (Table 3 ). According to the survey, the numbers of large livestock (yak) and small livestock (sheep and goats) per household in the study area were 31.6 and 56.9, respectively (Table 4). Compared with the towns' statistical data, the number of small livestock per household has decreased by $16.87 \%$ between 2000-2005, and 26.58\% between 2000-2010. (Table 5).

\section{Rapid transition to market economy}

Market forces shape the socioeconomic prospects of local herders. According to the survey, 34 households used to work near cities as bricklayers, drivers, maintenance workers, and restaurant
Table 2. Average productive performances of yak in the study area (2010).

\begin{tabular}{lrr}
\hline \hline Town & Beef $(\mathrm{kg})$ & Milk $(\mathrm{kg})$ \\
\hline Nagqu & 101.8 & 76.3 \\
Luoma & 95.6 & 73.4 \\
Kongma & 98.9 & 73.7 \\
Total & 98.5 & 74.4 \\
\hline
\end{tabular}

Table 3. Comparison of yak productivity in 1991, 1999, and 2010 in the study area.

\begin{tabular}{lrr}
\hline \hline Year & Beef $(\mathrm{kg})$ & Milk $(\mathrm{kg})$ \\
\hline 1991 & $105.9^{1}$ & $107.6^{1}$ \\
1999 & $101.5^{1}$ & $88.4^{1}$ \\
2010 & 98.5 & 74.4 \\
\hline
\end{tabular}

${ }^{1}$ Yang (2002)

Table 4. Number of livestock per household in the study area.

\begin{tabular}{lccc}
\hline \hline Town & $\begin{array}{c}\text { Population per } \\
\text { household }\end{array}$ & $\begin{array}{c}\text { Yaks per } \\
\text { household }\end{array}$ & $\begin{array}{c}\text { Sheep and goats per } \\
\text { household }\end{array}$ \\
\hline Nagqu & 5.1 & 27.8 & 46.7 \\
Luoma & 6.1 & 38.5 & 65.7 \\
Kongma & 5.4 & 28.6 & 57.3 \\
Total & 5.5 & 31.6 & 56.9 \\
\hline
\end{tabular}

attendants. Some individuals even moved to the cities to establish small businesses, e.g., restaurants, hotels, and clothing stores.

Moreover, herders in the study area were encouraged to join the formal pastoral cooperatives to obtain more benefits. Formal 
pastoral cooperatives, 3 in Nagqu Town, 2 in Luoma Town, and 1 in Kongma Town have been established, with 35 of the surveyed households being members of 1 of these cooperatives. Moreover, 14 households, who heard the success stories of cooperative members, were enticed to join the cooperatives. Statistics show that the mean animal husbandry income of members of the pastoral cooperatives was higher than that of those who did not join the cooperatives (3,194 RMB per person vs. 2,390 RMB per person; $\mathrm{t}=5.86, \mathrm{P}<0.01$ ). Through simple processes, the milk collected from members of the cooperatives was made into butter, yogurt, and other products, and these were sold to tourists or city residents. The price of milk paid by the cooperative was $26 \mathrm{RMB} /$ $\mathrm{kg}$ in winter and $20 \mathrm{RMB} / \mathrm{kg}$ in summer, which was higher than the market price, usually $22 \mathrm{RMB} / \mathrm{kg}$ in winter and $16 \mathrm{RMB} / \mathrm{kg}$ in summer.

Table 5. Comparison of livestock number in 2000, 2005, and 2010 in the study area.

\begin{tabular}{lcc}
\hline \hline Year & Yaks per household & $\begin{array}{c}\text { Sheep and goats per } \\
\text { household }\end{array}$ \\
\hline 2000 & $30.1^{1}$ & $77.5^{1}$ \\
2005 & $32.5^{1}$ & $66.5^{1}$ \\
2010 & 31.6 & 56.9 \\
\hline
\end{tabular}

${ }^{1}$ Township records

The formal pastoral cooperatives have some similarities with the collectivization management of the 1960s and 1970s. For example, households combined their properties to achieve higher economies of scale. However, they differed in a number of ways. First, herders joined the cooperatives voluntarily and had the freedom to quit. Second, production factors, including pastures, livestock, milk, labors, and funds, were still privately owned by households and were invested as capital stock, with each member of the cooperative sharing in the benefits and risks according to the capital stock he or she invested. Finally, unlike traditional community herd management, which aimed to maintain subsistence and avert environmental risks, the cooperatives were more market oriented, and the main reason for household participation was to increase revenue.

Based on the survey, the largest cooperative was founded and established in June 2005. As the manager (Brob) recounted: "At that time, only my neighbors, relatives, and some poor households wanted to join. Now, the cooperative has grown to 368 members. Some of the members provide financial support (ranging from 50 to $200 \mathrm{RMB}$ ) for the development of the cooperative, whereas others provide milk, which could be made into butter and yogurt and then sold to urban residents and tourists (Fig. 2)."

However, not all cooperatives operate smoothly. As the leader of another cooperative explained: "Brob's cooperative looks like an ideal project. The favorable conditions, interest-free loans provided by banks and sales channels provided by the local government, are not available to every cooperative. Although the local government has established sales networks to connect all sales outlets in Luoma Town, communication among them remains limited."
Fig. 2. Planting forage grass to maintain forage supply.

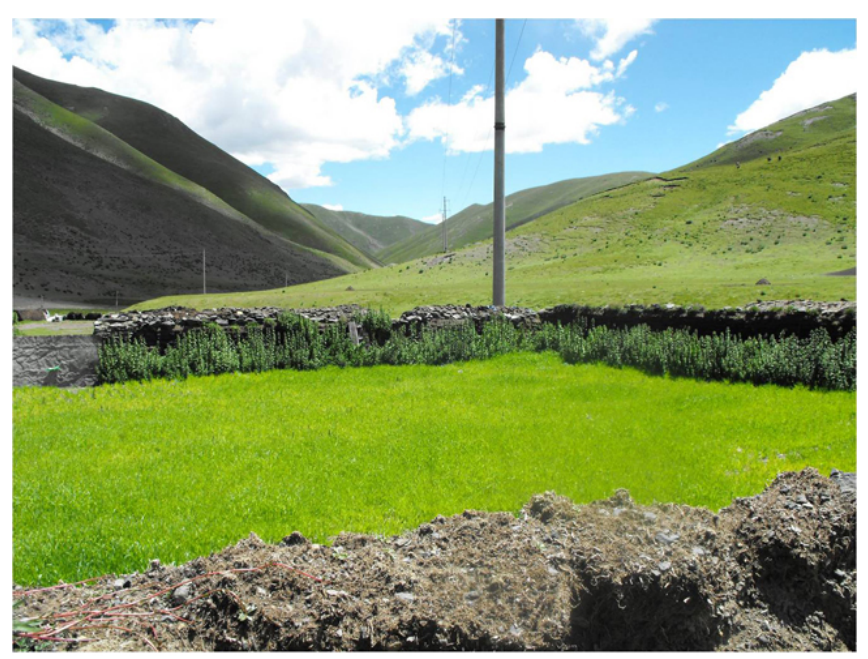

In addition, to join the formal pastoral cooperatives, other market-oriented adaptation strategies, such as buying fodder and planting forage grasses are also becoming increasingly important. According to the survey, almost all the households (126 households) purchased fodder, most commonly barley straw, in 2010 (Table 6). Households spent approximately 1500 RMB on average, which was nearly half of their expenditure on livestock production. As a result of irreversible effects of pasture degradation, most herders are expected to purchase more fodder in the coming years. This situation would undoubtedly increase their dependence on the external market. Table 6 shows that a total of 117 households bought grass seedlings with an average cost of $326 \mathrm{RMB}$ per household, which they could plant near their settlements. They generally agreed that planting forage grass could increase forage reserves and prepare them for extreme weather events, such as snowstorms. However, the high requirements for water, soil, and technological conditions limit large-scale cultivation.

Table 6. Local herders' adaptive activities to maintain forage supply.

\begin{tabular}{|c|c|c|c|c|}
\hline \multirow[t]{2}{*}{ Town } & \multicolumn{2}{|c|}{ Purchase fodder } & \multicolumn{2}{|c|}{ Plant forage grass } \\
\hline & $\begin{array}{c}\text { Number } \\
\text { of } \\
\text { households }\end{array}$ & $\begin{array}{l}\text { Average } \\
\text { expense } \\
(\mathrm{RMB})\end{array}$ & $\begin{array}{l}\text { Number of } \\
\text { households }\end{array}$ & $\begin{array}{l}\text { Average } \\
\text { expense } \\
\text { (RMB) }\end{array}$ \\
\hline Nagqu & 39 & 1425 & 34 & 256 \\
\hline Luoma & 41 & 1790 & 37 & 292 \\
\hline Kongma & 46 & 1290 & 46 & 405 \\
\hline Total & 126 & 1500 & 117 & 326 \\
\hline
\end{tabular}

Opening of the Qinghai-Tibet railway

With the opening of the Qinghai-Tibet railway, the links between the local and the outside world are becoming increasingly close. Convenient transportation has brought cheap goods, as well as 
introduced the popular culture and consumerism of major cities. However, it has caused a series of socioeconomic risks.

Approximately $30 \%$ of the surveyed households, mostly from villages near the railway, expressed that their current livelihoods were positively and negatively affected by the opening of the railway to some extent. As Brob said: "The sales of milk products have significantly increased as a large number of tourists came to Nagqu." However, other herders stated that the established railway divided their pastures into two parts. Unfortunately, one part of the pastures near the railway was forbidden for grazing. If livestock was found climbing the railway embankment, herders would be fined, which was usually $150 \mathrm{RMB}$ per violation. This situation prompted the herders to sell part of their livestock because pastures would be insufficient. Moreover, the railway channel was too narrow, which could harm grazing livestock.

Increasing demand for natural products and services The demand for natural products and services has been increasing in recent years as people's living standards improved. In the study area, caterpillar fungus has brought considerable income for local pastoralists (Table 7). Approximately a third of the surveyed households gathered caterpillar fungus in 2010. The average income that these households earned from the highly valued product reached almost $10,000 \mathrm{RMB}$, which accounts for nearly half of their total income.

Table 7. The impact of caterpillar fungus collection on local herders' income.

\begin{tabular}{lcc}
\hline \hline Town & Number of households & $\begin{array}{c}\text { Income from Cordyceps sinensis } \\
\text { collection (average/minimum/ } \\
\text { maximum RMB) }\end{array}$ \\
\hline Nagqu & $10 / 41$ & $13425 / 1000 / 40000$ \\
Luoma & $8 / 45$ & $9360 / 3000 / 30000$ \\
Kong- & $27 / 50$ & $8315 / 1000 / 76000$ \\
ma & $45 / 136$ & $9636 / 1000 / 76000$ \\
Total & &
\end{tabular}

Despite significant benefits from the collection of caterpillar fungus, this practice is not a stable source of income, as indicated by the fluctuating market prices of caterpillar fungus in 2006 to 2008. Moreover, in the wake of global climate change, the yield of caterpillar fungus is likely to be extremely unstable. Herders in the survey also expressed their concerns about the sustainability of caterpillar fungus collection. According to Donggar: "The caterpillar fungus resource might be exhausted someday. I do not know what I would do when that time comes." Yaddo shared: "Although the output of caterpillar fungus is increasing this year (2011), it does not mean that it will not decrease in the next year as herders from other areas might destroy the habitat of the fungus and its insect host."

\section{DISCUSSION AND RECOMMENDATIONS}

Our analysis revealed that the dynamics of Tibetan rangeland SES are driven by the combined impacts of climate and global change. Through cross-scale interaction, the impacts of climate and global change are upsetting the balance of the systems, reducing their resilience, and increasing their vulnerability (Kinzig et al. 2006). As Table 8 illustrates, factors such as climate warming, privatization of rangeland use rights, sedentarization and fencing, opening of the Qinghai-Tibet railway, and increasing demand for natural products and services contribute to the declining quality of rangeland resources and resource systems. This declining quality decreases the overall vegetation production and plant diversity, fragments rangelands, and causes distributed overgrazing. Furthermore, rangeland degradation, along with the increasing snowstorms and poor construction design, i.e., the narrow railway channel, also pose great challenges to livestock systems or resource units. The common property system characteristics of pastoralism, such as high mobility to escape environmental crises and collective action among households, are breaking down as common rangelands are privatized. Moreover, sedentarization and fencing isolates and locks out herders from their contracted pastureland, i.e., governance systems. Hence, changes in rangeland resource systems, livestock systems, and governance systems would affect herders' livelihood capital, i.e., users; more specifically it would affect (1) natural capital, related to rangeland biodiversity, (2) financial capital, related to the output of livestock products, and (3) social capital, related to social networks, which facilitate cooperation and enable people to act collectively for mutual benefits. Although local herders have developed various adaptation strategies, such as planting forage grass, buying fodder from market, renting pastures, joining formal or informal cooperatives, and diversifying livelihoods, social, cultural, and institutional challenges remain.

The impacts of global change on the vulnerability of Tibetan pastoral systems are more serious than those of climate change. The significant increase in the Tibetan population and livestock, the dramatic changes in rangelands and livestock management policies, and the intervention of market forces triggered by the global change have weakened pastoralists' ability to benefit from rangelands. Although global change has brought many challenges, more opportunities are available if more special resources of the rangelands could be used and discovered. To enhance herders' adaptive capacity and reduce their vulnerability, the opportunities offered by global changes must be seized. The three primary policy recommendations are summarized as follows:

\section{(1) Providing comprehensive support for the formal and informal pastoral cooperatives}

In the context of privatization, the establishment of pastoral cooperatives, which could encourage higher economies of scale, is deemed important to increase herders' income. In particular, pasture-user groups or livestock-herding groups that expand the range of individual households' resource utilization and promote community cooperation might reduce the tension between he users and the rangeland resource systems. However, the development of pastoral cooperatives also comes with challenges, such as lack of funds, imperfect sales systems, and products with low added value. Therefore, the government must provide cooperatives with various resources, such as startup funds, skills training, and market access. More importantly, the government is expected to create flexible institutions, which would enable members of the cooperatives to make their own decisions.

(2) Capturing the multifunctionalities of rangeland resources Pastoralism in its traditional form is centered on the provision of products and services for local herders' basic subsistence. 
Table 8. Factors and interactions that determine the vulnerability of the Tibetan pastoral systems.

\begin{tabular}{|c|c|c|c|}
\hline Driving forces & Negative effects & Adaptation strategies & Dilemma and challenges \\
\hline $\begin{array}{l}\text { Long-term, gradual } \\
\text { climate changes }\end{array}$ & $\begin{array}{l}\text { - Decrease the overall rangeland } \\
\text { production (Klein et al. 2004, 2008) } \\
\text { - Decrease the overall plant diversity } \\
\text { (Klein et al. 2004, 2008) } \\
\text { - Shorten the growing season (Dorji } \\
\text { et al. 2013) } \\
\text { - Increase rangeland pests (Interview } \\
\text { survey) } \\
\text { - Livestock that eat the rangeland } \\
\text { pests will be poisoned (Interview } \\
\text { survey) }\end{array}$ & $\begin{array}{l}\text { - Plant forage grass (Wu and } \\
\text { Richard 1999, Bai et al. 2012; } \\
\text { Interview survey) } \\
\text { - Rent pastures (Yeh and } \\
\text { Gaerrang 2011; Interview } \\
\text { survey) } \\
\text { - Purchase fodder from market } \\
\text { (Wang 2011; Interview survey) }\end{array}$ & $\begin{array}{l}\text { High technical requirement (Interview survey) } \\
\text { - High pasture-renting price (Yeh and Gaerrang } \\
\text { 2011; Interview survey) } \\
\text { - High fodder price (Wang 2011; Interview } \\
\text { survey) } \\
\text { - Increased labor intensity (Interview survey) }\end{array}$ \\
\hline Discrete, one-off events & $\begin{array}{l}\text { - Destroy houses (Interview survey) } \\
\text { - Heavy losses of livestock (Wu and } \\
\text { Yan 2002; Interview survey) }\end{array}$ & $\begin{array}{l}\text { - Plant forage grass (Wu and } \\
\text { Richard 1999; Interview } \\
\text { survey) } \\
\text { - Build winter shelters (Wu } \\
\text { and Richard 1999; Interview } \\
\text { survey) } \\
\text { - Purchase fodder from market } \\
\text { (Wang 2011; Interview survey) } \\
\text { - Rent pastures (Yeh and } \\
\text { Gaerrang 2011; Interview } \\
\text { survey) } \\
\text { - Join pastoral cooperatives } \\
\text { (Interview survey) } \\
\text { - Government relief (Interview } \\
\text { survey) } \\
\text { - Low-interest loans (Interview } \\
\text { survey) }\end{array}$ & $\begin{array}{l}\text { - High technical requirement (Interview survey) } \\
\text { - High fodder price (Wang et al. 2011; Interview } \\
\text { survey) } \\
\text { - High pasture-renting price (Yeh and Gaerrang } \\
\text { 2011) } \\
\text { - High cost of organizing cooperatives } \\
\text { (Interview survey) }\end{array}$ \\
\hline $\begin{array}{l}\text { Privatization of rangeland } \\
\text { use rights }\end{array}$ & $\begin{array}{l}\text { - Rangeland fragmentation (Wu and } \\
\text { Richard 1999, Richard et al. 2006; } \\
\text { Interview survey) } \\
\text { - Reduce spatial mobility of } \\
\text { livestock herds (Goldstein and Beall } \\
\text { 1990, Wu and Richard 1999, Miller } \\
\text { 2005, Yan et al. 2005, Richard et al. } \\
\text { 2006, Klein et al. 2011) } \\
\text { - More difficult access to water } \\
\text { resources (Wu and Richard 1999, } \\
\text { Yan et al. 2005) } \\
\text { - Increase boundary conflicts (Wu } \\
\text { and Richard 1999, Yeh 2003, Yan et } \\
\text { al. 2005; Interview survey) } \\
\text { - Increase labor inputs and gender } \\
\text { bias (Wu and Richard 1999, Yan et } \\
\text { al. 2005; Interview survey) } \\
\text { - Greater isolation of individual } \\
\text { households (Wu and Richard 1999, } \\
\text { Yan et al. 2005) }\end{array}$ & $\begin{array}{l}\text { - Common use of pastures } \\
\text { (Banks et al 2003, Richard et } \\
\text { al. 2006; Interview survey) }\end{array}$ & $\begin{array}{l}\text { - High cost of organizing cooperatives } \\
\text { (Interview survey) }\end{array}$ \\
\hline $\begin{array}{l}\text { Sedentarization and } \\
\text { fencing }\end{array}$ & $\begin{array}{l}\text { - Rangeland degradation near the } \\
\text { settlement (Wu and Yan 2002; } \\
\text { Interview survey) } \\
\text { - Reduce spatial mobility of } \\
\text { livestock herds (Goldstein and Beall } \\
\text { 1990, Wu and Richard 1999, Miller } \\
\text { 2005, Yan et al. 2005, Richard et al. } \\
\text { 2006, Klein et al. 2011) } \\
\text { - Widen gap between the rich and } \\
\text { poor (Bauer 2005; Interview survey) } \\
\text { - Weaken traditional social ties and } \\
\text { partnerships (Bauer 2005) } \\
\text { - Greater isolation of individual } \\
\text { households(Wu and Richard 1999, } \\
\text { Yan et al. 2005) }\end{array}$ & $\begin{array}{l}\text { - Common use of pastures } \\
\text { (Banks et al 2003, Richard et } \\
\text { al. 2006; Interview survey) }\end{array}$ & $\begin{array}{l}\text { - High cost of organizing cooperatives } \\
\text { (Interview survey) }\end{array}$ \\
\hline
\end{tabular}




$\begin{array}{ll}\text { Rapid transition to } & \text { - Weaken traditional social ties and } \\ \text { market economy } & \text { partnerships (Yeh and Gaerrang } \\ & \text { 2011) } \\ \text { - Widen gap between the rich and } \\ \text { poor (Interview survey) } \\ \text { - Increase gender bias (Interview } \\ \text { survey) }\end{array}$

Opening of the QinghaiTibet railway

Increasing demand for natural products and services such as caterpillar fungus

- More fragmented rangeland

(Interview survey)

- More occupied pastures (Interview survey)

- Herders will be fined if their livestock were to climb the railway embankment (Interview survey)

- Livestock that cross the narrow railway channel might be injured (Interview survey)

- The habitat for caterpillar fungus has been seriously damaged (Wang et al. 2011)
- Children required to dig caterpillar fungus with their parents and have less opportunity for school (Wang 2011; Interview survey)
- Join pastoral cooperatives (Interview survey)

- Work in towns and cities

(Fischer 2008, Kreutzmann

2011; Interview survey)

- Skills training (Interview

survey)

- Low-interest loans (Interview

survey)

- Sell livestock (Interview survey)

- High cost of organizing cooperatives (Interview survey)

- Low levels of literacy (Fischer 2008; Interview survey)

- Language barrier (Fischer 2008; Interview survey)

- Work in towns and cities (Fischer 2008, Kreutzmann 2011; Interview survey) - Skills training (Interview survey)

- Low-interest loans (Interview survey)

- Issue collection certificate (Wang et al. 2011)
- Loss of traditional way of insurance

(Interview survey)

- Low levels of literacy (Fischer 2008; Interview survey)

- Language barrier (Fischer 2008; Interview survey)
- Over-reliance on the caterpillar fungus industry (Wang et al. 2011)
- Decreased caterpillar fungus production
(Wang et al. 2011)
- Price fluctuations and market risks (Wang et al. 2011)

However, rangelands have increasingly been recognized as multifunctional and have thus begun providing a wide range of ecosystem services, which are of paramount importance not only to millions of local inhabitants but also to billions who live beyond the rangeland areas. The study area is becoming host to an increasing number of tourists, who are attracted by the beautiful scenery and unique local culture. This cultural service provided by the rangeland could promote diversification of pastoralists' livelihoods, thereby increasing their adaptive capacity to environmental risks.

\section{(3) Revitalizing the mobility paradigm}

The mobility paradigm allows flexible use of rangelands and empowers herders to gain access to key sites or high-value grazing patches. However, the intensive government development paradigm, which focuses on maximizing livestock production, still prevails. Hence, is there still potential to revitalize the mobility paradigm? The answer might be yes. The survey indicates that members of pasture-user groups or livestock-herding groups were spontaneously pooling their livestock into larger herds to be herded on shared pastures, and some households remained in their pastures as a way of pasture leasing to mitigate their loss of mobility. However, reconstructing a large-scale mobile paradigm is difficult because technical, financial, and institutional support is required from all levels of government. The national government needs to develop flexible policies, which could provide legal space for alternative rangeland management models, such as community-based management. Hence, the local government should develop effective mechanisms to coordinate and regulate the movement path between different locations and provide modern and convenient transport facilities for herders to transfer their livestock.

\section{CONCLUSIONS}

We used the analytical framework developed by Ostrom (2009) to perform an integrated analysis of the dynamics of Tibetan pastoral systems affected by climate and global changes. Results showed that climate and global changes have significantly altered the attributes of and the interactions within Tibetan rangeland SES, thus posing great challenges to their sustainable development. Nagqu County, a remote area of the northern Tibetan Plateau of China, was selected as a case study to analyze the adaptation strategies employed by local herders to respond to multiple stressors and to investigate opportunities, which could help herders increase their adaptive capacity. Findings indicate that although local herders have developed various adaptation strategies, such as planting forage grass, buying fodder from the market, renting pastures, joining formal or informal cooperatives, and diversifying their livelihoods, social, cultural, and institutional challenges remain. To enhance herders' adaptive capacity and reduce their vulnerability, policies that advocate flexible rangeland and livestock management are highly recommended.

\section{Responses to this article can be read online at: http://www.ecologyandsociety.org/issues/responses. php/6803}

\author{
Acknowledgments: \\ Our research is supported by the National Key Research \\ Development Plan (2010CB951704) and Peking University- \\ Lincoln Institute Dissertation Fellowships. We thank Wu yingying, \\ Qi wei, Hua xiaobo, Liu xiang, Yao lina and Peng cuo for their help
}


with the field survey. Special thanks must go to all the hospitable Tibetan herders, who are always patient with our endless questions.

\section{LITERATURE CITED}

Bai, W.-Q., Y.-L. Zhang, L.-S. Liu, Q.-Q. Zhang, and C.-J. Du. 2012. Adaptation of Tibetan nomadism to climate change in the source region of the Yellow River. Journal of Natural Resources 27(12):2030-2038. [online] URL: http://www.jnr.ac.cn/EN/ abstract/abstract2533.shtml

Banks, T. J., C. Richard, P. Li, and Z. L. Yan. 2003. Communitybased grassland management in Western China: rationale, pilot project experience, and policy implications. Mountain Research and Development 23:132-140. http://dx.doi.org/10.1659/0276-4741 (2003)023[0132:CGMIWC]2.0.CO;2

Bauer, K. 2005. Development and the enclosure movement in pastoral Tibet since the 1980s. Nomadic Peoples 9:85-115. http:// dx.doi.org/10.3167/082279405781826119

Christensen, J. H., B. Hewitson, A. Busuioc, A. Chen, X. Gao, I. Held, R. Jones, R. K. Kolli, W.-T. Kwon, R. Laprise, V. Magaña Rueda, L. Mearns, C. G. Menéndez, J. Räisänen, A. Rinke, A. Sarr, and P. Whetton. 2007. Regional climate projections. Chapter 11 in S. Solomon, D. Qin, M. Manning, Z. Chen, M. Marquis, K. B. Averyt, M. Tignor, and H. L. Miller, editors. Climate change 2007: the physical science basis. Contribution of Working Group I to the Fourth Assessment Report of the Intergovernmental Panel on Climate Change. Cambridge University Press, Cambridge, New York, New York, USA. [online] URL: http:// www.ipcc.ch/publications and data/publications_ipcc_fourth_assessment report wg1 report the physical science basis.htm

Dong, S., L. Wen, S. Liu, X. Zhang, J. P. Lassoie, S. Yi, X. Li, J. $\mathrm{Li}$, and Y. Li. 2011. Vulnerability of worldwide pastoralism to global changes and interdisciplinary strategies for sustainable pastoralism. Ecology and Society 16(2): 10. [online] URL: http:// www.ecologyandsociety.org/vol16/iss2/art10/

Dorji, T., Ø. Totland, S. R. Moe, K. A. Hopping, J. B. Pan, and J. A. Klein. 2013. Plant functional traits mediate reproductive phenology and success in response to experimental warming and snow addition in Tibet. Global Change Biology 19(2):459-472. http://dx.doi.org/10.1111/gcb.12059

Du, F. 2012. Ecological resettlement of Tibetan herders in the Sanjiangyuan: a case study in Madoi County of Qinghai. Nomadic Peoples 16(1):116-133. http://dx.doi.org/10.3167/ np.2012.160109

Fischer, A. M. 2008. Subsistence and rural livelihoods strategies in Tibet under rapid economic and social transition. Journal of the International Association of Tibetan Studies 4:1-49. [online] URL: http://www.thlib.org/collections/texts/jiats/\#!jiats=/04/fischer/

Foggin, J. M. 2008. Depopulating the Tibetan grasslands, national policies and perspectives for the future of Tibetan herders in Qinghai province, China. Mountain Research and Development 28 (1):26-31. http://dx.doi.org/10.1659/mrd.0972

Fu, Y., E. Grumbine, A. Wilkes, Y. Wang, J.-C. Xu, and Y.-P. Yang. 2012. Climate change adaptation among Tibetan pastoralists: challenges in enhancing local adaptation through policy support. Environmental Management 50(4):607-621. http:// dx.doi.org/10.1007/s00267-012-9918-2
Goldstein, M. C., and C. M. Beall. 1990. Nomads of western Tibet: the survival of a way of life. University of California Press, Berkeley, California, USA.

Kinzig, A. P., P. Ryan, M. Etienne, H. Allison, T. Elmqvist, and B. H. Walker. 2006. Resilience and regime shifts: assessing cascading effects. Ecology and Society 11(1): 20. [online] URL: http://www.ecologyandsociety.org/vol11/iss1/art20/

Klein, J. A., J. Harte, and X.-Q. Zhao. 2004. Experimental warming causes large and rapid species loss dampened by simulated grazing on the Tibetan Plateau. Ecology Letters 7 (12):1170-1179. http://dx.doi.org/10.1111/j.1461-0248.2004.00677. $\underline{x}$

Klein, J. A., J. Harte, and X.-Q. Zhao. 2007. Experimental warming, not grazing, decreases rangeland quality on the Tibetan Plateau. Ecological Applications 17(2):541-557. http://dx.doi. org/10.1890/05-0685

Klein, J. A., E. Yeh, J. Bump, Y. Nyima, and K. Hopping. 2011. Coordinating environmental protection and climate change adaptation policy in resource-dependent communities: a case study from the Tibetan Plateau. Page 423-438 in J. D. Ford and L. Berrang-Ford, editors. Climate change adaptation in developed nations: from theory to practice. Springer, New York, New York, USA. http://dx.doi.org/10.1007/978-94-007-0567-8 31

Kreutzmann, H. 2011. Pastoral practices on the move - recent transformations in mountain pastoralism on the Tibetan Plateau. Pages 200-224 in H. Kreutzmann, Y. Yang, and J. Richter, editors. Pastoralism and rangeland management on the Tibetan Plateau in the context of climate and global change. Federal Ministry for Economic Cooperation and Development, Berlin, Germany. [online] URL: http://www.geo.fu-berlin.de/geog/fachrichtungen/ anthrogeog/zelf/Medien/download/Kreutzmann_PDFs/pdfs_Nov_2012/ GIZ2011 Tibet-pastoralism-management.pdf

Li, W. J., and L. Huntsinger. 2011. China's grassland contract policy and its impacts on herder ability to benefit in Inner Mongolia: tragic feedbacks. Ecology and Society 16(2): 1. [online] URL: http://www.ecologyandsociety.org/vol16/iss2/art1/

Long, R. J., X. Y. Liu, G. X. Cui, and W. M. Zhang. 2011. Socioeconomic changes in pastoral systems on the Tibetan Plateau. Pages 239-255 in H. Kreutzmann, Y. Yang, and J. Richter, editors. Pastoralism and rangeland management on the Tibetan Plateau in the context of climate and global change. Federal Ministry for Economic Cooperation and Development, Berlin, Germany. [online] URL: http://www.geo.fu-berlin.de/geog/fachrichtungen/ anthrogeog/zelf/Medien/download/Kreutzmann_PDFs/pdfs_Nov_2012/ GIZ2011 Tibet-pastoralism-management.pdf

Miller, D. J. 2005. The Tibetan Steppe. Pages 305-341 in J. M. Suttie, S. G. Reynold, and C. Batello, editors. Grasslands of the world. Food and Agriculture Organization of the United Nations (FAO), Rome, Italy. [online] URL: http://postconflict.unep.ch/ sudanreport/sudan_website/doccatcher/data/documents/Grasslands $\%$ 20of $\% 20$ the $\% 20$ World.pdf

Næss, M. W., D. Lhagyal, D. Yangzom, P. Mathiesen, J. L. Fox, and B. J. Bårdsen. 2004. Nomadic pastoralism in the Aru basin of Tibet's Chang Tang. Rangifer 15:39-46. [online] URL: http:// www.cwru.edu/affil/tibet/booksAndPapers/Naess-ChangTang-Rangifer. pdf 
Ni, J. 2003. A simulation of biomes on the Tibetan Plateau and their responses to global climate change. Mountain Research and Development 20(1):80-89. http://dx.doi.org/10.1659/0276-4741 (2000)020[0080:ASOBOT]2.0.CO;2

Nyima, T. 2003. China case study 3: pastoral systems, change, and the future of grazing lands in Tibet. Pages 151-187 in J. M. Suttie, and S. B. Reynolds, editors. Transhumant grazing systems in temperate Asia. Plant production and protection, series 31. Food and Agriculture Organization of the United Nations (FAO), Rome, Italy. [online] URL: http://www.fao.org/docrep/006/ $\mathrm{y} 4856 \mathrm{e} / \mathrm{y} 4856 \mathrm{e} 00 . \mathrm{HTM}$

Ostrom, E. 2005. Understanding institutional diversity. Princeton University Press, Princeton, New Jersey, USA.

Ostrom, E. 2011. Background on the institutional analysis and development framework. Policy Studies Journal 39(1):7-27. http:// dx.doi.org/10.1111/j.1541-0072.2010.00394.X

Ptackova, J. 2011. Sedentarisation of Tibetan nomads in China: implementation of the nomadic settlement project in the Tibetan Amdo area; Qinghai and Sichuan Provinces. Pastoralism: Research, Policy and Practice 1:4. http://dx.doi.org/10.1186/2041-7136-1-4

Richard, C. 2005. Developing alternatives to resettlement for pastoralists on the Tibetan Plateau. Nomadic Peoples 9 (1-2):103-106. http://dx.doi.org/10.3167/082279405781826173

Richard, C., Z. Yan, and G. Du. 2006. The paradox of the individual household responsibility system in the grasslands of the Tibetan Plateau, China. United States Department of Agriculture Forest Service Proceedings RMPS-P-39. USDA Forest Service, Fort Collins, Colorado, USA. [online] URL: http://www.cwru. edu/affil/tibet/booksAndPapers/RMRS-P-39-6-Camille_Richard. pdf

Shang, K. Z., L. Y. Chen, H. Zhou, S. G. Wang, and D. B. Yang. 2010. Variation trend of climate and the prediction in the Northern Qinghai-Tibet Plateau. Journal of Anhui Agricultural Science 38(6):3009-3012.

Tashi, G., and M. Foggin. 2012. Resettlement as development and progress? Eight years on: review of emerging social and development impacts of an 'ecological resettlement' project in Tibet Autonomous Region, China. Nomadic Peoples 16 (1):134-151. http://dx.doi.org/10.3167/np.2012.160110

Wang, J. 2011. Integrating agricultural and pastoral resources for poverty alleviation and reducing eco-pressure on rangelands. Pages 225-238 in H. Kreutzmann, Y. Yang, and J. Richter, editors. Pastoralism and rangeland management on the Tibetan Plateau in the context of climate and global change. Federal Ministry for Economic Cooperation and Development, Berlin, Germany. [online] URL: http://www.geo.fu-berlin.de/geog/fachrichtungen/ anthrogeog/zelf/Medien/download/Kreutzmann_PDFs/pdfs_Nov_2012/ GIZ2011 Tibet-pastoralism-management.pdf

Wang, M., K. Tashi, G. Zhuo, and B. Dan, 2011. Contribution of Cordyceps sinensis to Tibetan pastoralist income and problems in its sustainable use. Pages 165-176 in H. Kreutzmann, Y. Yang, and J. Richter, editors. Pastoralism and rangeland management on the Tibetan Plateau in the context of climate and global change. Federal Ministry for Economic Cooperation and Development, Berlin, Germany. [online] URL: http://www.geo.fu-berlin.de/
geog/fachrichtungen/anthrogeog/zelf/Medien/download/ $\underline{\text { Kreutzmann_PDFs/pdfs_Nov_2012/GIZ2011_Tibet-pastoralism- }}$ management.pdf

Wilkes, A. 2008. Towards mainstreaming climatic change in grassland management policies and practices on the Tibetan Plateau. Working Paper Number 67. World Agroforestry Centre, Nairobi, Kenya.

Wu, N., and C. Richard. 1999. The privatization process of rangeland and its impacts on the pastoral dynamics in the HinduKush Himalaya: the case study of Western Sichuan, China. Pages 14-21 in D. Eldridge and D. Freudenberger, editors. People and rangelands. Proceedings of VI International Rangelands Congress, Townsville, Australia. [online] URL: http://www.eldis. org/fulltext/IRCFinal.pdf

Wu, N., and Z. Yan. 2002. Climate variability and social vulnerability on the Tibetan Plateau: dilemmas on the road to pastoral reform. Erdkunde 56:2-14. http://dx.doi.org/10.3112/ erdkunde.2002.01.01

Wu, S. H., Y. H. Yin, D. Zheng, and Q. Y. Yang, 2005. Climate changes in the Tibetan Plateau during the last three decades. Acta Geographica Sinica 60(1):3-11.

Wu, S., Y. Yin, D. Zheng, and Q. Yang. 2007. Climatic trends over the Tibetan Plateau during 1971-2000. Journal of Geographical Sciences 17(2):141-151. http://dx.doi.org/10.1007/s11442-007-0141-7

Yan, Z. L., N. Wu, D. Yeshi, and J. Ru. 2005. A review of rangeland privatization and its implications in the Tibetan Plateau, China. Nomadic Peoples 9:31-51. http://dx.doi.org/10.3167/082279405781826155

Yan, J., Y. Wu, and Y. Zhang. 2011. Adaptation strategies to pasture degradation: gap between government and local nomads in the eastern Tibetan Plateau. Journal of Geographical Sciences 21(6):1112-1122. http://dx.doi.org/10.1007/s11442-011-0904-Z

Yang, X. Q. 2002. Yak production and strategy for its further development in Nagqu Prefecture of Tibet, P.R. China. Pages 335-337 in Proceedings of the third international congress on yak, in Lhasa, China, 4-9 September 2000. International Livestock Research Institute (ILRI), Nairobi, Kenya.

Yeh, E. T. 2003. Tibetan range wars: spatial politics and authority on the grasslands of Amdo. Development and Change 34 (3):499-523. http://dx.doi.org/10.1111/1467-7660.00316

Yeh, E. T. 2005. Green governmentality and pastoralism in Western China: 'converting pastures to grasslands.' Nomadic Peoples 9(1-2):9-30. http://dx.doi.org/10.3167/082279405781826164

Yeh, E. T., and Gaerrang. 2011. Tibetan pastoralism in neoliberalising China: continuity and change in Gouli. Area 43 (2):165-172. http://dx.doi.org/10.1111/j.1475-4762.2010.00976.x

Yu, H. Y., E. Luedeling, and J. C. Xu. 2010. Winter and spring warming result in delayed spring phenology on the Tibetan Plateau. Proceedings of the National Academy of Sciences 107 (51):22151-22156. http://dx.doi.org/10.1073/pnas.1012490107

Zhao, X., H. Zhang, and J. Wan. 2002. The impact of climate change on the climate zones in the Qinghai-Tibetan Plateau. Scientia Geographica Sinica 22(2):190-195. 